\title{
Evaluating Forest Management in Nepal: Views across Space and Time
}

\author{
$\underline{\text { Harini Nagendra }}^{1}$, Mukunda Karmacharya $^{2}$, and Birendra Karna ${ }^{2}$
}

\begin{abstract}
This research follows the manner in which State-driven, upwardly accountable, forest decentralization programs play out on the ground, and evaluates their impact on forests and local institutions, a topic of much current concern and debate. In a landscape in Nepal's Terai plains, we conducted a census of 23 co-managed community and buffer-zone forest user groups-two predominant approaches to involving communities in forest-management activities in Nepal's Terai plains - to draw statistically relevant conclusions about the relative impact of these two programs at a landscape scale. We use a multidate Landsat TM® image classification to develop a land-cover change classification, and use this to generate objective, quantitative, biophysical indicators that enable us to assess the extent of clearing and regeneration in the forest areas controlled and managed by each of these communities. In-depth field interviews with the communities provide us with information about the impact of these initiatives on local institutions. Finally, we link these two kinds of information sets to interpret the satellite information on forest-cover change with reference to the socioeconomic processes and management rules that influence forest-cover change in these regions. Satellite image analysis shows the regeneration of several patches of forest that are managed within the purview of the Royal Chitwan National Park's buffer-zone program. This can be related to high levels of investment in plantation and forest-management activities by external agencies. The substantial revenue that these communities derive from ecotourism also helps, allowing them to hire forest guards, and afford better monitoring capabilities. In contrast, the less wealthy, communityforestry user groups have to make do with volunteer patrols, and do not have the same level of external technical and financial support to invest in plantation activities. Buffer-zone users, however, have to deal with rather strict controls on export of forest products, which were put in place by park authorities, and which the users do not have the power to modify. Downward accountability is limited, and communities do not have a high degree of effective control over forest-management policies. Thus, local communities currently function under a situation of constraint, where they have been delegated responsibilities, but lack the devolution of property rights and decision-making power. This has significant and potentially negative implications for the future of the program.
\end{abstract}

Key Words: buffer zone; community forestry; co-management; institutions; land-cover change; Nepal; protected area; remote sensing

\section{INTRODUCTION}

In response to escalating concerns about the degradation of State-managed forests, developing countries around the world are increasingly promoting decentralization of natural resource management (Ribot 2002, 2004a, 2004b). From the State-centric policies that were promoted in different parts of the world in the mid- $20^{\text {th }}$ century, the trend has shifted toward encouraging participatory systems of management by local communities (Bray et al. 2003, Prasad and Kant 2003). This shift has been prompted by recognition of the numerous problems associated with consolidating all power in the hands of the State, and of the crucial, hitherto unrecognized, positive role played by local communities - albeit nudged by international shifts in policy. 
Decentralization can be defined as "any act by which a central government formally cedes powers to actors and institutions at lower levels in a political, administrative and territorial hierarchy" (Ribot 2004b). However, in practice most of these efforts at decentralization lead to either privatization or deconcentration of power from central to State or district governments, and only rarely result in the strengthening of local institutions (Agrawal and Ostrom 2001, Ribot 2002, 2004a, 2004b). Programs that apparently aim at decentralization tend to emanate from State initiatives or pressure by external aid agencies. Such programs tend to be implemented by official machinery in a manner that results in the delegation of responsibilities and liabilities, yet keeps most of the benefits and the power firmly vested in the hands of the State, without any real downward accountability (Poffenberger and McGean 1996, Sundar 2000, Ribot 2002, 2004a, 2004b; but see Bray et al. 2003 for a very interesting discussion of highly successful, exceptional "bottom-up" initiatives in Mexico).

Among developing countries, Nepal was an early leader in initiating innovative programs of forest management aimed at involving local communities (Agrawal et al. 1999, Agrawal and Ostrom 2001). Since 1976, the Nepali government has experimented with a variety of programs aimed at decentralizing forest management, beginning with Panchayat forestry and moving toward community forestry, leasehold forestry, and parks-and-people programs (Gautam et al. 2004). This small mountain country thus provides a very interesting ground to examine State-implemented, collaborative, comanagement initiatives, where the Government seeks to involve local people in the management of their forests - an increasing trend across the globe today (Wollenberg et al. 2004).

Organized forest management on a large scale began in Nepal around 1880, with establishment of forest inspection offices and timber offices throughout the country. A central Forest Management Office was opened in 1924 at the national level, which was managed by the ruling Rana dynasty (Palit 1996). Despite these official structures and institutions, before the mid-1950s, most of the forests of Nepal were not under State control, but rather under community control. Traditional and indigenous forest management practices were prevalent during this period
(Messerschmidt 1987, Thapa and Weber 1995), with the crucial difference that the population was small and the forest resources relatively large, so that pressure on the forest was nowhere near the level that exists today.

After the fall of the ruling Rana dynasty in 1950, the new rulers of Nepal passed the Nationalization Act of 1957, which brought all forest land, as well as all trees planted on private land, under government ownership. As in many other developing countries, where previously limitedaccess resources managed by common property regimes existed, the process of nationalization created open-access resources and led to exacerbated degradation (Ostrom 1990, 2000). Replacing local control over forest resources with an ineffective, sometimes corrupt, central governance system resulted in large-scale devastation of forest cover (Bajracharya 1983, Neupane 2000).

The first significant step toward adopting community forestry approaches was taken during the Ninth Forestry Conference, held in Kathmandu in 1974. The National Forest Act of 1976, and its subsequent amendments of 1977 and 1978, attempted to return some degree of ownership and control over forest resources to the people through Panchayat forestry. These programs were not very successful, and the Community Forestry Act was subsequently introduced in 1993 to achieve the same objectives (Thapa and Weber 1995, Varughese 1999). By 1999, rapid expansion of this program had resulted in over 620000 ha of forest area being handed over by the Forest Department, which had previously managed these forests, to 8500 forest user-group committees to manage (Chaudhary 2000).

Most community forests are located in the middle hills, where several studies argue that these programs have been successful in improving the conditions of people and forests (as summarized in Chakraborty 2001, Gautam et al. 2004). In contrast, only $17 \%$ of all area under community forestry is located in the Terai (lowlands) of Nepal (Hobley 1996 in Chakraborty 2001). Strong reservations have been expressed about the feasibility of community forestry in the Terai (Brown 1998, Chakraborty 2001, Gautam et al. 2004). There is much controversy about the impact of these programs in this region, with the State threatening to limit the management of these programs by local 
communities by further constraining their ability to harvest timber from the forest, and demanding a percentage of the revenues from forest extraction (Neupane 2000, Mahapatra 2001, Nagendra 2002). Unlike the middle hills, where the initiation and expansion of community forestry has been largely driven by local communities, in the Terai these initiatives are, to a larger extent, government driven. Furthermore, the decisions and performance of the management committees tend to be upwardly accountable to government officials, rather than downwardly accountable to the local communities themselves.

Given the biophysical, socioeconomic, and institutional differences between these two regions, there is a pressing need to investigate this controversial issue through empirical evaluations using primary data from the Terai (Heinen and Mehta 2000, Nagendra 2002). Such research will provide crucial information about the manner in which State implementation of co-management plays out in a context where traditional institutions have been marginalized by an extremely high proportion of recent migrants, and where the challenge for the State is to create and facilitate new institutions of community management. This research combines information on forest change with an analysis of decentralization initiatives in Nepal's Terai plains to follow the human dimensions of forest change in this region. Our study area is located in the Chitwan District, in the forests around Nepal's oldest protected area, the Royal Chitwan National Park (RCNP). We study two main recent initiatives toward co-management of forests in the Nepal Terai: the community forestry and buffer-zone management programs (Chaudhary 2000, Schweik et al. 2003).

Much of our current understanding about the management of the commons is derived from richly detailed analyses of a single community or a very small set of case studies (Agrawal 2001). These qualitative studies of the commons, although very valuable for providing detailed insights into the workings of a single community, suffer from potentially significant problems in methodology, especially if statistically relevant answers about the impact of different causal factors are sought. This study draws on remote sensing and geographic information systems (GIS) analyses of multiple communities using a common research framework to expand the scope of such studies, and to derive statistically significant conclusions about the success or failure of different policy initiatives at a broader level. We canvassed all 23 co-managed community and buffer-zone forests within our landscape and used these data to draw statistically relevant conclusions about the relative impact of the two programs. Multi-date Landsat TM® image classification is used to generate objective, quantitative, biophysical indicators that enable us to assess the extent of clearing and regeneration in each of our study forests. In-depth field interviews with the communities are used to evaluate the impact of these initiatives on local institutions. Finally, we link these two kinds of information sets to offer a more complete picture of these two decentralization initiatives in Nepal, and to evaluate how they have played out on the ground, in terms of both impacting forest conservation and affecting local communities. This research thus follows the manner in which State-driven, upwardly accountable, forest decentralization programs play out in reality, and evaluates their impact on forest condition and local institutions, a topic of much current concern and debate.

\section{STUDY AREA}

Nepal displays very distinct physiographic patterns that enable its division into three major zones: the Terai, the middle hills, and the mountains. Located along the Nepal-India border, the Terai region of Nepal constitutes the foothills and valleys below the Himalayan mountains. The indigenous inhabitants of the region (the Tharus) practised a form of shifting cultivation, and preferred slightly elevated areas along rivers to protect against flood and wild animal damage (Guneratne 1994, Müller-Böker 1999). The swampy vegetation and high incidence of malaria kept the population levels low.

In the early 1950 s, a malaria eradication program in the Terai opened the way for settlement of this densely forested area. In response to growing food shortages throughout the middle hills, the Nepali government initiated programs of settlement for agriculture in 1951 (Mathews et al. 2000). Around the same time, the World Health Organization began a major effort to eradicate malaria through a largescale DDT spray program in 1953. By $1970,91 \%$ of the previously affected region was declared malaria free (Guneratne 1994, Müller-Böker, 1999). From 1927 to 1977 , it is estimated that the forested areas in the Terai decreased by almost $60 \%$. Concomitant with these changes, has been an 
increase in the conversion of forest to farmland, and farmland to urban area (Mathews et al. 2000). Large parts of this once thickly forested land have been converted to a densely populated mix of agriculture and forests.

In comparison with the middle hills, low initial population densities in the Terai led to the existence of fewer traditional institutions of forest management. Thus, the challenge for the Terai has been to create and support new institutions of forest management (Gautam et al. 2004). The traditional inhabitants have been pushed away from the forests by economically and socially powerful hill migrants, and the communities living in close proximity to the forest edge are largely composed of very heterogeneous groups of migrants from the middle hills, without traditional historical, cultural, or social ties to the region. The high timber value of forests in the Terai provides a perverse incentive for corruption and illegal harvesting, and acts as an additional bone of contention between the State and local communities (Mahapatra 2001, Poudel 2001).

Concerns about the effectiveness of community management in the Terai have led the Nepal government to propose an amendment to the Forest Act of 1993, with the new subclauses limiting community forestry within the Terai, and implementing new regulations that limit the independence of these communities by requiring them to get permission from the Forest Department for forest harvesting activities, and to share $40 \%$ of their income with the State (Poudel 2000, 2001). These initiatives have, understandably, caused high levels of concern in the user communities, which perceive them as an usurpment of their rights, and plan to protest their implementation (Neupane 2000, Mahapatra 2001, Gautam et al. 2004). Despite this controversy, compared with the abundance of studies in the middle hills, there has been comparatively very little research examining the impact of decentralization programs on forests and people in this region.

The Chitwan District of southern Nepal is an inner valley Terai district, located between the middle hills to the north, and the Siwalik ranges to the south. The climatic regime is tropical monsoon, with rainy summers and almost dry winters. The first national park of Nepal, the Royal Chitwan National Park (RCNP), was established in Chitwan in 1973. Semideciduous forests constitute the climax vegetation in this region (Stainton 1972). Timber harvesting and agriculture have given rise to stages of secondary succession that include mixed hardwood and more open forest and, eventually, tall and short grasses. In addition, tropical, deciduous, riverine forest patches are found along the banks of rivers and streams, along with patches of grassland, bamboo, and swampy vegetation in these areas (Stainton 1972, Negi 1998).

Chitwan experienced a doubling of population between 1971 and 1991, with an annual population growth rate of $3.3 \%$ (Matthews et al. 2000). The district now contains a complex mix of ethnicities, with people from all over the country. Most agriculture in the region is carried out by small, subsistence farmers, who remain dependent on the forest for fuelwood, fodder, and non-timber forest products. The pressure on forests is high, with as much as $75 \%$ of the population actively harvesting products from the surrounding forests (Matthews et al. 2000). The rapid increase in deforestation has prompted the government to launch community forestry programs, which has led to significant regrowth in some regions, although there is continuing degradation in other parts (Schweik et al. 2003). Chitwan District thus provides a challenging case study of the human dimensions of forest change in a one-time frontier forest converted over the last 40 years into a complex, shifting mosaic of forest, agriculture, settlement, and clearings.

The study area is located in the eastern half of the Chitwan District, and borders the RCNP at its northern end (Fig. 1). We restricted the landscape used for our study to an area that was similar in terms of elevation and other biophysical landscape attributes likely to harbor forest cover, for purposes of greater comparability. The communities that live in this region are largely composed of migrants from the middle hills, and do not vary significantly across the study area in terms of their ethnic composition or levels of dependence on the forest.

The East-West highway, a major all-weather road that links Chitwan to the national capital Kathmandu, cuts diagonally through the study area. Forest patches located north of the highway fall within the purview of the community forestry program, and those located south of the highway, and closer to the RCNP, are part of the RCNP Buffer Zone (RCNP-BZ) program.

The Fourth Amendment to the National Parks and 
Fig. 1. Location of study area in East Chitwan, Nepal

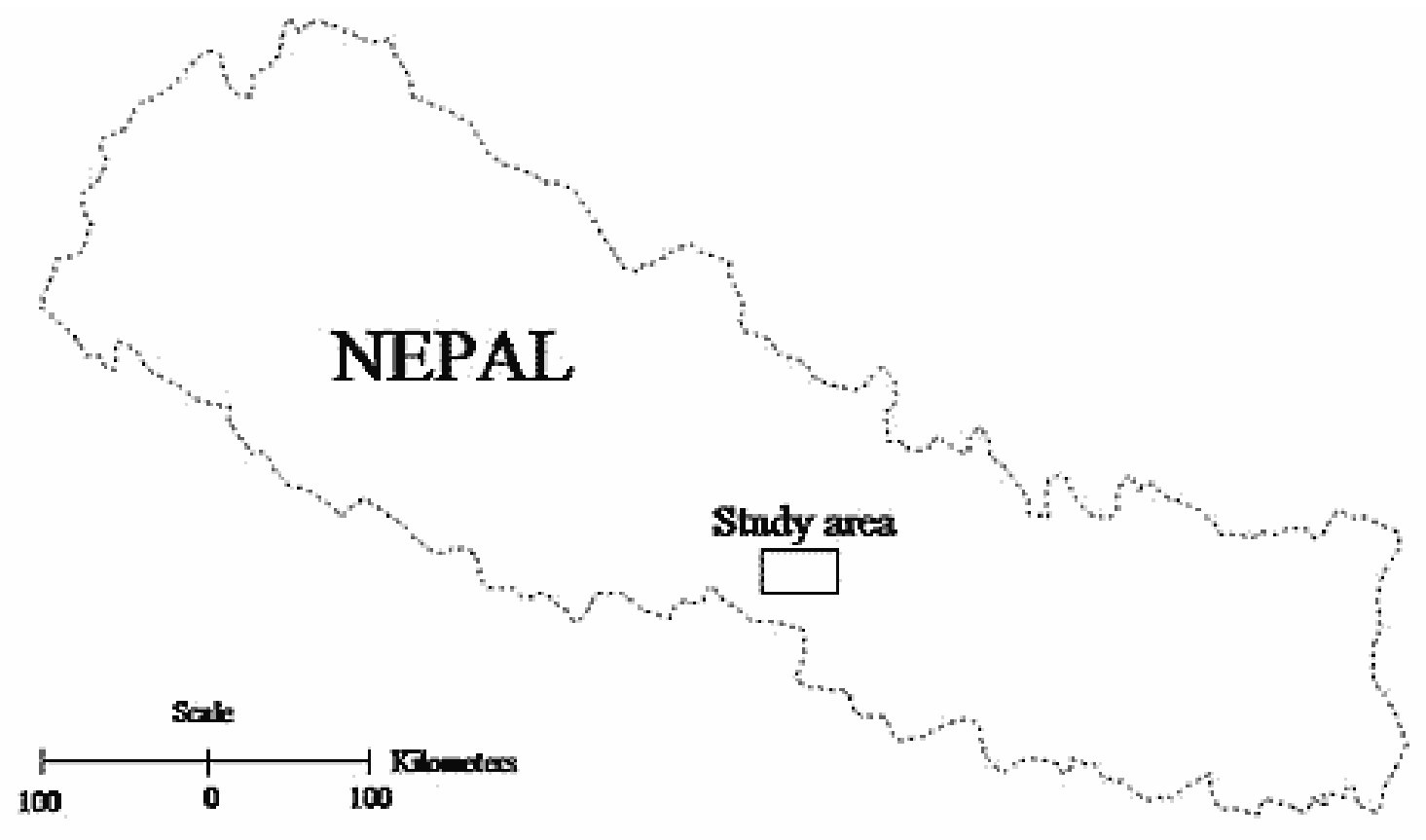

Wildlife Conservation Act, passed in 1993, gave the Department of National Parks and Wildlife Conservation (DNPWC) the legal power to establish buffer zones in forested areas surrounding parks where forest resources are used on a regular basis by locals (Heinen and Mehta 1999, 2000). The DNPWC began implementing the Park People Program in the Chitwan and in other protected areas of Nepal in early 1995, to fulfill two primary objectives: socioeconomic wellbeing of the bufferzone communities and biodiversity conservation of the parks and their surrounding forests (Maskey et al. 1999). This program receives financial and technical assistance from the United Nations Development Programme (UNDP), and has since been rechristened the Participatory Conservation Project.

Following the initiation of the buffer-zone program, specific forest areas near the park boundary were identified and delineated by the RCNP Warden.
Local communities that used this forest and harvested products from this region were identified to constitute buffer-zone management committees. The forests were then handed over to these usergroup committees to manage (instead of being managed by the park authorities as was previously the case), in accordance with the Buffer Zone Management Guidelines (HMG 1999). The bufferzone regulations and guidelines are fairly restrictive. They allow committees to maintain their own accounts, but user groups must spend $40 \%$ of their income on conservation, followed by $30 \%$ on community development, $20 \%$ on income generation and skill development, and $10 \%$ on administration (HMG 1999, Heinen and Mehta 2000). The warden retains the power at all times to stop projects, and acts as the secretary of the committee overseeing expenditures (Heinen and Mehta 1999, 2000).

Based on the Master Plan for the Forestry Sector in 
1988, the Forest Act of 1993 authorizes the District Forest Officer to hand over any part of a national forest to a user group in the form of a community forest. Communities then develop an operational forest management plan, which is subsequently ratified by the Forest Department. This enables them to conserve and manage these forests, and sell and distribute products, including forest timber, by independently setting the prices (Shreshtha 1998). An amendment to the Act in 1998 mandated that the user group should invest at least $25 \%$ of its income into forest development and conservation activities (Gautam et al. 2004). Recent amendments have attempted to place further restrictions on the harvest and sale of forest products, and distribution of the resulting income, and have met with stiff resistance from the Federation of Community Forest Users in Nepal (FECOFUN).

\section{METHODS}

\section{Satellite Image Processing}

Three data sets were used for this study. The first set of data came from U.S. Landsat Thematic Mapper (TM) images. This satellite data set allowed us to provide an explicitly temporal perspective, and to examine the forests in Chitwan before and after initiation of community management programs. Satellite images provide a spatial synoptic and through-time view of forests and biodiversity (Nagendra 2001). Applications of remote-sensing techniques to analyze social incentives and actions, and to explore environmental and social change have been increasingly explored over the past few years (Liverman et al. 1998, Fox et al. 2003, Schweik et al. 2003, Nagendra et al. 2004). The temporal perspective afforded by analysis of multidate satellite images is essential in order to place the changes seen in the forests in their proper context, and to follow the impact of changes in management regimes on forest cover over time.

Landsat TM images have been extensively used for research on human-forest interactions, even in the tropics, where the extent of vegetation complexity and landscape fragmentation is fairly high (Liverman et al. 1998, Fox et al. 2003). These images contain information from seven sensors which enables us to distinguish broad types of land cover, such as forest, agriculture, soil, and water. In previous research in the same region, we used Landsat TM imagery with great effectiveness to identify and categorize active, successful forest management institutions (Schweik et al. 2003). Multi-temporal satellite image analysis provides us with objective, quantitative information on the extent of forest regrowth within the areas managed by each of our communities of interest. These images also allow us to go back in time and develop an accurate spatial map of forest cover before the initiation of these management programs, which would not otherwise be possible.

Two nearly cloud-free Landsat TM images (from 24 January 1989 and 27 March 2000) were selected to analyze changes in forest cover between 1989 and 2000. Both images were taken during the premonsoon season, when the distinction between fallow agriculture and tree cover is marked and easy to distinguish. This analysis allowed us to evaluate efforts toward community forestry in the Terai over the last decade, during which community-based programs have seen the most activity in the Terai. The 1989 image was georeferenced using 1:25000 scale topographic maps; the 2000 image was georeferenced to the 1989 image with an RMS error of less than 0.5 pixels. This enabled us to overlay information from different images within a GIS to evaluate forest change. Radiometric calibration, atmospheric correction, and radiometric rectification procedures were used to ensure image comparability (Jensen 2000). Without such calibration, changedetection analysis may evaluate differences at the sensor level rather than changes at the Earth's surface.

A normalized difference vegetation index (NDVI) (Jensen 2000) was computed for the calibrated images. This index can range from -1 to +1 , and is believed to relate strongly to the amount of vegetation cover on ground. Between February and May 2000, field training data were collected on the distribution of forest cover in the Chitwan. These data were used to identify thresholds of NDVI values that correspond to cleared areas, open tree cover (less than $40 \%$ canopy cover), and dense tree cover (more than $40 \%$ canopy cover), respectively. These thresholds were used to classify the NDVI images for 1989 and 2000 into the above three categories using ERDAS IMAGINE® software. 


\section{Geographical Information Systems (GIS) Analysis}

Individual land cover images for 1989 and 2000 were recoded to provide a single image that identified change trajectories (i. e., sequences of land cover classes across observation dates, Petit et al. 2001). The output was a categorical "change image," where each pixel now includes information on land cover for both dates. Areas of no change indicated pixels that remain in the same land-cover category across both dates, whereas areas of deforestation experienced a decrease in forest cover, and areas of regrowth experienced an increase in forest cover (Fig. 2). The regrowth, or increase, in tree cover can be due to replanting saplings, or to natural regeneration. In most forests, the communities use both these approaches to encourage regrowth. As it is not possible to distinguish between replanting and "natural" reforestation through remote sensing, and because the scale of variation in these management practices is too detailed to map in the field, we treated both as instances of regrowth. By incorporating information from images taken on both dates, change trajectories highlighted the dynamic character of the land cover within the study region (Mertens and Lambin 1997, 2001). We used ARC/ INFO $^{\text {TM }}$ GRID software, a raster-based program, for this procedure.

\section{Management Boundaries, Property Rights, and Rules}

This study was conducted at a landscape scale, and within our study landscape, we conducted a complete census of all community forest and bufferzone community user groups that were active and functioning at the time of our visit. Our initial checklist identified 14 functioning, registered buffer-zone forests and nine functioning, registered community forestry user groups located in the study area. We interviewed each of these communities, showed them topographic maps of the region, and obtained information from them on the exact location and boundaries of the forests under their control. Each community was associated with a single, spatially connected, forest patch-except in the case of one of the forest communities, which managed two adjacent, but spatially distinct, forest patches. The spatial boundary of each of these forest patches was determined by walking around the perimeter of the forest using a geographical positioning system (GPS) unit, as well as by using information from local forest users and forest officials to locate the boundary on a 1:25000 scale survey topographical map with reference to major landmarks. This spatial information on management boundaries was collected during the months of March and April 2002.

The spatial boundaries were converted to digital form and overlaid onto the change trajectory satellite image. Using ArcInfo GRID, we calculated the percentage of total forest area for each of these forest patches that remained stable, experienced deforestation, or experienced regrowth. Then, we classified these pixels according to the management regime (community forest or buffer-zone forest).

Agrawal and Ostrom (2001) summarize previous research on the commons as having identified four categories of property rights that are crucial to understand common-pool resource management: withdrawal, management, exclusion, and alienation. In the context of forest resources, these can be described in more detail as the right to withdraw specified forest products from a defined physical area; the right to manage a forested patch, regulate use patterns, and make improvements; the right to determine exclusion, that is, to determine who has the right to withdraw forest products and how this right can be transferred; and the right to alienate, that is to sell or lease withdrawal, management, and exclusion rights. We use this approach to compare the property regimes in place in community forestry and in the buffer zone, using information derived from our interviews with local users, and from the management guidelines.

We also collected information on the rules and processes impacting forest management in these two regimes. This was done through in-depth interviews with each buffer-zone forest community user group, based on the institutional survey forms developed by the International Forestry Resources and Institutions (IFRI) Program (Ostrom 1998, Poteete and Ostrom 2004). The IFRI program is a long-term, cross-country, comparative study of forests and local institutions conducted in 11 countries, at last count in 157 sites around the world. The research protocols that this program uses were developed by an interdisciplinary team of scientists at Indiana University, and have been extensively validated over the past decade by several teams of researchers working at various locations. These forms provided us with information on selected 
Fig. 2. 1989-2000 change classification for East Chitwan, overlaid with community-forest and buffer-zone boundaries

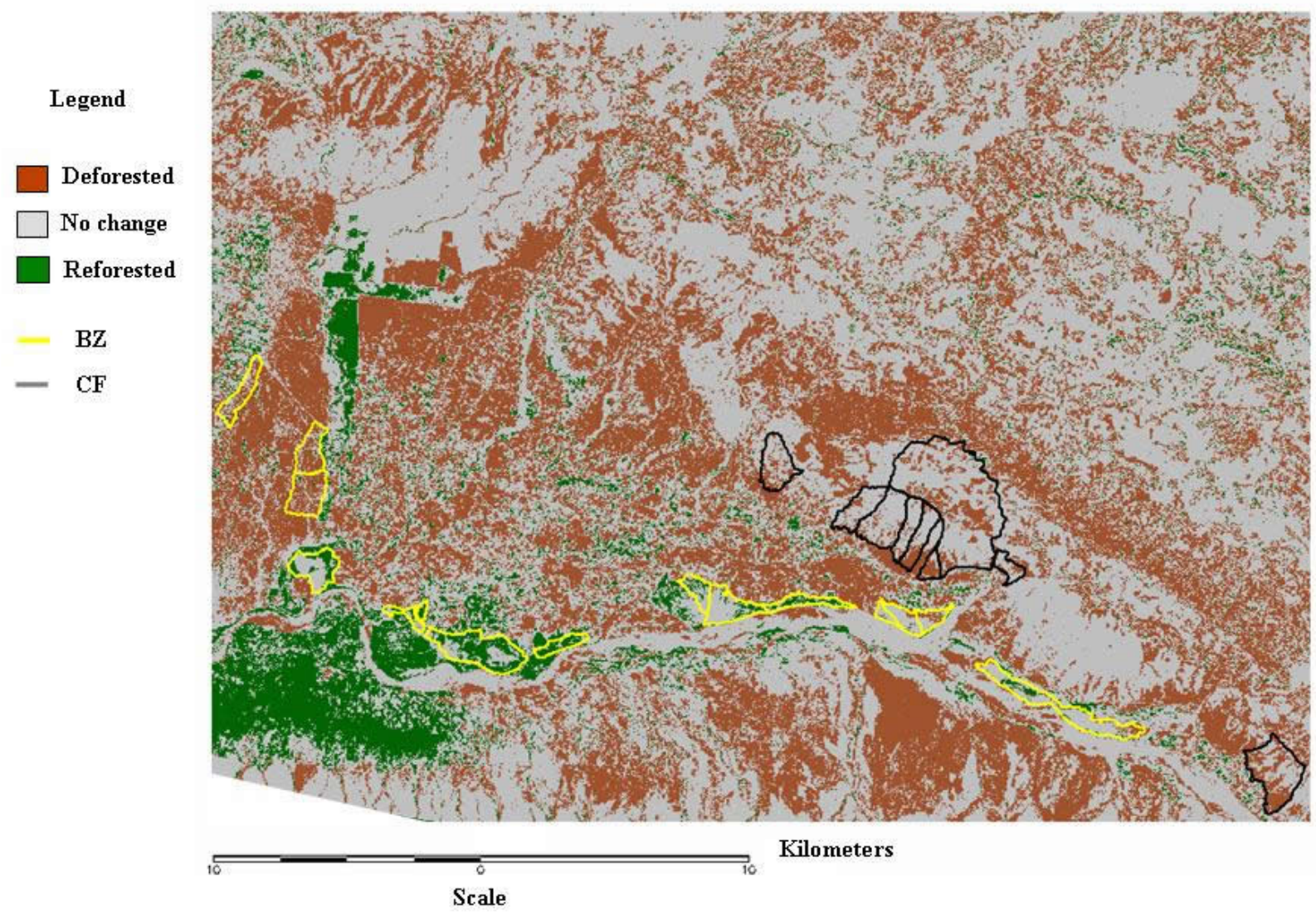

variables believed to be crucial in impacting the effectiveness of local institutions and rules-in-use, including management practices, forest area, usergroup size, number of livestock and cattle, income derived from the user group, monitoring activities, and ability to modify the rules.

\section{RESULTS AND CONCLUSIONS}

We found differences between the two management regimes in terms of the property rights regimes within which they function, the monitoring and harvesting rules, the ability to modify rules, and the external technical and financial support (Table 1). We also found that there was substantial variation in terms of other parameters such as forest size, user group size, and income derived from the forest, which could be related to the satellite image derived information on forest cover change within the boundary of that patch (Table 2). Used in conjunction with each other, these variables allowed us to interpret the satellite information on forest cover change with reference to the socio-economic processes and management rules that influence forest cover change in these regions.

In general, the buffer-zone user groups had limited ability to create or modify operational rules of management, and were only permitted to harvest a limited set of products from the forest, during certain times of the year (as specified by the park authorities). The major source of income earned by 
Table 1. Comparison of the buffer-zone and community-forest management regimes in terms of operational rules, property rights, sources of income, and external investments.

\begin{tabular}{ll}
\hline \hline Community forests \\
\hline Who develops the rules? & $\begin{array}{l}\text { The community, following which } \\
\text { approval by the Forest Department is } \\
\text { required. }\end{array}$ \\
Power to modify rules & $\begin{array}{l}\text { Limited capacity to modify some } \\
\text { management rules, after obtaining } \\
\text { approval from the Forest Department. }\end{array}$ \\
Forest management & $\begin{array}{l}\text { Occasional planting of trees, regular } \\
\text { silvicultural operations with assistance } \\
\text { of Forest Department. }\end{array}$
\end{tabular}

\section{Buffer-zone forests}

Harvesting rules

Harvesting of grasses, fallen wood, leaf litter generally permitted. Restricted harvest of timber.

The constitution of the user groups is developed from the initial set of rules provided by the RCNP authorities.

Highly limited. Buffer-zone user groups do not officially have the authority to modify many of the forest management rules.

Extensive planting of trees, and silvicultural activities conducted with the support of park authorities and the UNDP Parks and People program.

Harvest of fodder permitted, but only very limited harvest of other forest products during selected times of the year.

Rights to withdrawal

Rights to withdraw non-timber forest products, as well as to extract and sell timber after obtaining approval of the operational forest management plan from the Forest Department.

Rights to manage

Yes, with a limited degree of control over modifications to management systems.

Rights to exclude

Limited: the District Forest Officer decides membership in consultation with community. No authority to transfer rights to exclude.

Yes, but limited to those forest products authorized by the fairly strict management guidelines provided to the community.

Yes, but with very little or no control over modifications to management systems.

Limited: the Warden decides membership in consultation with community. No authority to transfer rights to exclude.

Rights to alienate

$\begin{array}{ll}\text { Equity } & \text { Women and lower castes sometimes } \\ \text { excluded from participation. }\end{array}$

Monitoring

Source of income

External technical and financial support

Mostly by local volunteers on a rotational basis, occasionally forest the case).

Largely through membership fees,
No rights to sale or transfer of the land itself, which is the property of the State.

No rights to sale or transfer of the land itself, which is the property of the State.

Women and lower castes sometimes excluded from participation.

Generally through hired forest guards, paid in cash. guards are hired when the community has enough money (which is usually not supplemented by sale of forest products.

Mostly through entry fees from tourists, supplemented by membership fees and sale of forest products.

High degree of external technical and financial support from the RCNP authorities, UNDP, KMTNC, and other external aid agencies. 
them was from tourism, supplemented by smaller revenues from annual user fees and the sale of firewood and other forest products. In contrast, community forestry user groups were not able to access income from tourism, and their major sources of revenue were from annual user fees, sale of firewood, medicinal plants, timber, and other forest products. These groups were unable to collect enough money to hire forest guards, and had to make do by using volunteers drawn from within the group, or even from the management committee, for monitoring activities. Buffer-zone user groups were, however, able to afford a better level of monitoring, because of the higher revenues they received, enabling them to hire forest guards. These groups also received extensive technical and financial support from the UNDP, the Biodiversity Conservation Prioritization Project (BCPP), King Mahendra Trust for Nature Conservation (KMTNC), and park authorities, and had conducted extensive plantation and forest maintenance activities, which, coupled with the better monitoring and limited harvest, encouraged greater forest regrowth compared with the community forests.

Table 2 describes the nine community forests and 14 buffer-zone forests in the study area, and provides information on their size, percentage of area that has experienced regrowth and deforestation between 1989 and 1991, user group size, annual income, and year in which forest protection was initiated. For purposes of confidentiality, the names of the settlements and forests are not provided here. Our interviews indicated that, in several of the buffer-zone areas, forest protection was initiated in response to a severe flood that devastated the area in 1993-1994. Although the buffer-zone program was formally initiated in 1998, Table 2 indicates that some communities began protecting the forest as far back as 1986. Similarly, the date of initiation of community protection for the community forests ranges from 1989 to 1996. An alternative hypothesis, therefore, could be that the forests that have been protected for longer periods of time are the areas showing less deforestation and greater regrowth. A rank correlation analysis, however, showed that there was no significant correlation between the number of years the forest had been protected, and the percentage of deforestation or regrowth.

Buffer-zone forests show a net increase and community forests show a net decrease in forest cover between 1989 and 2000 (Table 2). A nonparametric Mann Whitney $U$ test revealed that the percentage of deforestation was significantly lower and the percentage of regrowth significantly higher in buffer-zone forests compared with community forests $(\mathrm{p}<0.05)$. There is no significant difference between buffer-zone forests and community forests in terms of size (Fig. 2, Table 2), or in terms of user-group size (Table 2), but the user: forest ratio was significantly higher in buffer-zone forests $(p<0.05)$. Finally, there was no significant correlation between the date of initiation of forest protection, and percentage deforestation, or percentage regrowth, as demonstrated by a rank correlation analysis $(\mathrm{p}=0.05)$.

Remote sensing provides an effective means of quantifying the impact of different approaches to forest management on land-cover change. At the same time, it is important to recognize that analysis of remotely sensed data requires fieldwork to interpret human activities and incentives that relate to land-cover change, and to understand the underlying socioeconomic and institutional factors that drive forest-cover change in these regions (Moran and Brondizio 1998, Rindfuss and Stern 1998, Schweik and Green 1999, Fox et al. 2003). We used satellite imagery of constant spatial, spectral, and radiometric resolution (Landsat TM imagery) to examine the impact of these two management regimes on land-cover change over the past decade. Such analysis is difficult to do, as it is difficult to obtain remote-sensing data with constant characteristics over extended time scales because of changes in the sensors (Liu et al. 2002). We also used detailed information derived from interviews with user groups to interpret the changes that we observed in the images, and to project the impact of these changes into the future.

Satellite image analysis showed that there were significantly higher rates of regrowth and lower rates of deforestation in the buffer-zone forests over the past decade, compared with community forests. This corresponds with our findings from user-group interviews, which indicate that there are much stricter management policies in force in the buffer zone. Unlike the community forests, only limited harvesting of forest products is permitted in these forests. These strict rules regarding withdrawal were, however, largely developed by park authorities, and ignore the difficulties that this 
Table 2. Description of study forests

\begin{tabular}{|c|c|c|c|c|c|c|c|}
\hline $\begin{array}{l}\text { Management } \\
\text { Regime }\end{array}$ & $\begin{array}{l}\text { Total area } \\
\text { (ha) }\end{array}$ & $\begin{array}{l}\text { \% deforested } \\
(1989-2000)\end{array}$ & $\begin{array}{c}\text { \% regrowth } \\
(1989-2000)\end{array}$ & $\begin{array}{l}\text { User group } \\
\text { size }\end{array}$ & $\begin{array}{l}\text { User / } \\
\text { Forest ratio } \\
\text { (per ha) }\end{array}$ & Annual income & $\begin{array}{l}\text { Protection ini- } \\
\text { tiated }\end{array}$ \\
\hline $\mathrm{BZ}^{\mathrm{a}}$ & 95.9 & 4.60 & 56.43 & 450 & 4.69 & 150000 & 1989 \\
\hline $\mathrm{BZ}$ & 182.0 & 2.32 & 21.86 & 1880 & 10.33 & 15000 & 1998 \\
\hline $\mathrm{BZ}$ & 76.3 & 2.71 & 76.18 & 1100 & 14.42 & 80000 & 1993 \\
\hline $\mathrm{BZ}$ & 192.8 & 68.95 & 2.29 & 2100 & 10.89 & 14000 & 1995 \\
\hline BZ & 327.2 & 15.05 & 13.07 & 1866 & 5.70 & 7500 & 1992 \\
\hline $\mathrm{BZ}$ & 375.6 & 0.48 & 58.66 & 8000 & 21.30 & 75000 & 1996 \\
\hline BZ & 32.9 & 4.92 & 10.66 & 917 & 27.87 & 58000 & 1993 \\
\hline $\mathrm{BZ}$ & 85.6 & 15.14 & 2.52 & 1519 & 17.74 & 10000 & 1989 \\
\hline BZ & 47.7 & 0.94 & 42.26 & 5000 & 104.82 & 50000 & 1995 \\
\hline $\mathrm{BZ}$ & 85.5 & 4.74 & 24.21 & 1100 & 12.87 & 150000 & 1994 \\
\hline $\mathrm{BZ}$ & 64.5 & 38.49 & 24.21 & 1100 & 17.05 & 150000 & 1994 \\
\hline BZ & 130.3 & 56.42 & 3.18 & 6000 & 46.05 & 2400000 & 1986 \\
\hline $\mathrm{BZ}$ & 195.9 & 0.46 & 39.00 & 4570 & 23.33 & 10000 & 1989 \\
\hline $\mathrm{BZ}$ & 150.7 & 62.66 & 4.96 & 1280 & 8.49 & 30000 & 1995 \\
\hline $\mathrm{CF}^{\mathrm{b}}$ & 62.9 & 65.95 & 0.00 & 1235 & 19.63 & 70000 & 1995 \\
\hline $\mathrm{CF}$ & 199.7 & 37.40 & 0.14 & 3525 & 17.65 & 400000 & 1991 \\
\hline $\mathrm{CF}$ & 138.2 & 38.80 & 0.00 & 2444 & 17.68 & 80000 & 1992 \\
\hline $\mathrm{CF}$ & 129.5 & 18.21 & 0.00 & 1512 & 11.68 & 16000 & 1994 \\
\hline $\mathrm{CF}$ & 1272.2 & 28.78 & 0.31 & 3500 & 2.75 & 120000 & 1995 \\
\hline $\mathrm{CF}$ & 72.9 & 36.42 & 0.00 & 790 & 10.84 & 80000 & 1996 \\
\hline $\mathrm{CF}$ & 359.2 & 51.57 & 0.03 & 2690 & 7.49 & 25000 & 1993 \\
\hline $\mathrm{CF}$ & 166.7 & 17.87 & 0.00 & 1080 & 6.48 & 5100000 & 1989 \\
\hline $\mathrm{CF}$ & 265.9 & 18.82 & 0.07 & 1300 & 4.89 & 103000 & 1996 \\
\hline
\end{tabular}


creates for group members who depend on the forest for fodder, fuel, and other products.

Buffer-zone groups receive significantly greater revenues from tourism, which they can invest in hiring forest guards. Thus, they are able to enforce limitations on harvesting more easily than the less wealthy community forest user groups, which must depend largely on voluntary monitoring by group members. Furthermore, buffer-zone forests have received extensive financial and technical inputs from external aid agencies: most significantly the UNDP (Maskey et al. 1999), but also including Biodiversity Conservation Network, the World Wildlife Fund, and the KMTNC (Bookbinder et al. 1998, Heinen and Mehta 1999, 2000). With their support, substantial plantation and forest maintenance activities are conducted in these forests, which can account for much of the forest regeneration. Thus, we recommend that efforts be made to ensure that community forestry user groups are also provided with opportunities to derive income from tourism activities, which they may then invest in better monitoring and forest-management activities.

Although there are no significant differences in terms of forest size or user-group size, we find that the user group:forest ratio is significantly higher in the better protected buffer-zone forests. Recent work on the commons suggests that heterogeneity is a much more complex factor than previously recognized, and increased group size can, under certain conditions, even facilitate better management (Varughese and Ostrom 2001, Poteete and Ostrom 2004). Thus, our findings agree with those of Agrawal (2000), Agrawal and Goyal (2001), and Varughese (2000) in the western and central Himalayas, where larger forest groups appear to be more successful at managing forests, due in large part to the fact that more people are involved in management and monitoring. Obviously, increasing group size is only effective up to a point: as group size continues to increase beyond optimal levels, less and less coordination will result. However, it is important to recognize that, in areas where labor for forest maintenance activities and for guarding the forest is contributed by the local community, very small groups will not be able to function as effectively as medium-sized groups. This may be a factor influencing the relative success of bufferzone forests, which have a higher number of users potentially available to participate in management and monitoring activities per unit of forest area.
In a country like Nepal, where local biophysical, social, economic, and cultural conditions vary so markedly from one region to the next, allowing communities the flexibility to adapt management policies to local conditions is a crucial factor that impacts their success (Varughese and Ostrom 2001). Managing institutional change from the top down is not an easy task, and communities require the flexibility to incorporate context-specific learning into their management activities (Poffenberger and McGean 1996, Sundar 2000, Prasad and Kant 2003).

Although it is heartening to observe regeneration of forest cover in the buffer zone, we must also ask what degree of control do buffer-zone forest users have over determining, enforcing, and modifying the rules of management? Our interviews clearly indicate that there is limited downward accountability, and that local users lack the power to modify and enforce changes in management guidelines. The buffer-zone forest groups follow a pattern of behavior typical of many State-enforced institutions, being relatively inflexible and unable, or unwilling, to adapt to changing social or biophysical conditions that require changes in appropriate management practices (Berkes et al. 1998). Decision-making authority is not vested in the community, rather it still rests with the warden, and the user groups are not allowed to make significant changes to management policies. The user groups have limited decision-making authority over their forests, and thus, this management, although it may be effective in the short term, is not very participatory. Other scholars have shown that, in situations where the management framework is developed by the State to fulfill national objectives, responsiveness to local requirements is limited, leading to a loss in flexibility and adaptation to local circumstance (Wollenberg et al. 2004).

Another crucial concern relates to the time horizon of the buffer-zone program. The support provided to this program by its international donors has been demarcated for a specific period of time. What will be its future once the timeline of these projects is over, and international support is withdrawn? This raises questions about the future sustainability of the program. Buffer-zone communities are constrained by strict policies regarding withdrawal. Although these may appear effective in the short term, we have found they lead to social conflict between those users that participate in the program and those who are excluded from the program. 
These findings concur with results from multicountry case studies conducted by researchers such as Ribot (2004 a, 2004b) Wollenberg et al. (2004), Suryanata et al. (2003), and Agrawal and Ostrom (2001), who conclude that, in many if not most instances, decentralization reforms tend to be louder on the rhetoric and less developed on the ground. Often, these purported reforms lead neither to the strengthening of local communities, nor to the betterment of forests. Nepal's community forestry program in the middle hills is usually held up as an exception to this scenario, an example of a truly successful, community-initiated effort (Gautam et al. 2004, Chakraborty 2001), although this program also has its drawbacks.

In Nepal's Terai plains, where the effectiveness of these programs is hotly debated, we find that the program has led to definite, discernable improvements in forest cover. However, crucial variables that impact institutional effectiveness over the long term, namely institutional flexibility, local autonomy, and transfer of decision-making power to local institutions, are very limited. This lack of effective "democratic decentralization" (Ribot $2004 b$ ) is a important factor that may negatively impact the long-term sustainability and effectiveness of local institutions (Suryanata et al. 2003, Wollenberg et al. 2004, Ribot 2004b). The lack of flexibility to make changes to the management guidelines exposes the lack of downward accountability in the Terai, creating an additional burden on the local communities, which now have the added responsibility of managing their forests without being empowered to make their own changes to the management program. The local communities clearly require more than the delegation of responsibilities, as is currently the case; to ensure their buy-in, the devolution of rights, assets, and power is a must. Otherwise, although these efforts may be successful at maintaining biodiversity in limited protected park areas, they will not prove sustainable without significant funding, nor capable of the eventual goal of expansion to cover all protected areas in Nepal.

Responses to this article can be read online at: http://www.ecologyandsociety.org/vollo/iss 1/art24/responses/

\section{Acknowledgments:}

This research was supported by the National Science Foundation (NSF) (SBR-9521918) as part of the ongoing research at the Center for the Study of Institutions, Population, and Environmental Change (CIPEC) at Indiana University, and by the Society in Science: Branco Weiss Fellowship to HN. We are greatly indebted to Dr. Elinor Ostrom for starting us off on this very interesting path of research. We also thank Kanchan Thapa and Dr. Ganesh Shivakoti for assistance with planning and executing our field research, and Drs. Charles Schweik and George Varughese for many helpful discussions along the way. Finally, we are very grateful to Drs. Elinor Ostrom, Edward Webb and the anonymous referees of this manuscript for their invaluable feedback on earlier drafts of this paper.

\section{LITERATURE CITED}

Agrawal, A., C. Britt, and K. Kanel. 1999. Decentralization in Nepal: a comparative analysis. ICS Press, Oakland, California, USA.

Agrawal, A. and E. Ostrom. 2001. Collective action, property rights, and decentralization in resource use in India and Nepal. Politics and Society 29:485-514.

Agrawal, A. 2000. Small is beautiful, but is larger better? Forest-management institutions in the Kumaon Himalaya, India. Pages 57-85 in C. Gibson, M. McKean, and E. Ostrom, editors. People and forests: communities, institutions, and governance. MIT Press, Cambridge, Massachussetts, USA.

Agrawal, A. 2001. Common property institutions and sustainable governance of resources. World Development 29:1949-1672.

Agrawal, A., and S. Goyal. 2001. Group size and collective action: third party monitoring in common-pool resources. Comparative Political Studies 34:63-93.

Bajracharya, D. 1983. Deforestation in the food/ fuel context: historical and political perspectives 
from Nepal. Mountain Research and Development 3:227-240.

Berkes, F., C. Folke, and J. Colding, editors. 1998. Linking social and ecological systems: management practices and social mechanisms for building resilience. Cambridge University Press, Cambridge, UK.

Bookbinder, M. P., E. Dinerstein, A. Rijal, H. Cauley, and A. Rajouria. 1998. Ecotourism's support of biodiversity conservation. Conservation Biology 12:1399-1404.

Bray, D. B., L. Merino-Pérez, P. Negreros-Castillo, G. Segura-Warnholtz, P. M. Torres-Rojo, and H. F. M. Vester. 2003. Mexico's community managed forests as a global model for sustainable landscapes. Conservation Biology 17:672-677.

Brown, K. 1998. The political ecology of biodiversity, conservation and development in Nepal's Terai: confused meanings, means and ends. Ecological Economics 24:73-87.

Chakraborty, R. N. 2001. Stability and outcomes of common property institutions in forestry: evidence from the Terai region of Nepal. Ecological Economics 36:341-353.

Chaudhary, R. P. 2000. Forest conservation and environmental management in Nepal: a review. Biodiversity and Conservation 9:1235-1260.

Fox, J., R. R. Rindfuss, S. J. Walsh, and V. Mishra. 2003. People and the environment: approaches for linking household and community surveys to remote sensing and GIS. Kluwer Academic Publishers, Boston, Massachussetts, USA.

Gautam, A. P., G. P. Shivakoti, and E. L. Webb. 2004. A review of forest policies, institutions, and change in the resource condition in Nepal. International Forestry Review 6:136-148.

Guneratne, A. 1994. The Tharus of Chitwan: ethnicity, class and the state in Nepal. Dissertation, University of Chicago, Chicago, Illinois, USA.

Heinen, J. T., and J. N. Mehta. 1999. Conceptual and legal issues in the designation and management of conservation areas in Nepal. Environmental Conservation 26:21-29.
Heinen, J. T., and J. N. Mehta. 2000. Emerging issues in legal and procedural aspects of buffer zone management with case studies from Nepal. Journal of Environment and Development 9:45-67.

His Majesty's Government of Nepal (HMG). 1999. Buffer zone management guidelines. His Majesty's Government, Ministry of Forests and Soil Conservation and Department of National Parks and Wildlife Conservation, Kathmandu, Nepal.

Jensen, J. R. 2000. Remote sensing of the environment: an earth resource perspective. Prentice Hall. Upper Saddle River, New Jersey, USA.

Liu, J., M. Linderman, Z. Ouyang, L.An, J. Yang, and H. Zhang. 2002. Ecological degradation in protected areas: the case of Wolong Nature Reserve for Giant Pandas. Science 292:98-101.

Liverman, D., E. F. Moran, R. R. Rindfuss, and P. C. Stern, editors. 1998. People and pixels: linking remote sensing and social science. National Academy Press, Washington, D. C., USA.

Mahapatra, R. 2001. Betrayed: Nepal's forest bureaucracy prepares for the funeral of the muchhailed community forest management programme. Down To Earth 9(22):20.

Matthews, S. A., G. P. Shivakoti, and N. Chhetri, N. 2000. Population forces and environmental change: observations from western Chitwan, Nepal. Society and Natural Resources 13:763-775.

Maskey, T. M., S. Bajimaya, B. R. Dhamala, B. K. L. Joshi, and P. Budhathoki. 1999. Park people programme: 1999 the year in review.. Department of National Parks and Wildlife Conservation Parks People Programme and United Nations Development Programme, Kathmandu, Nepal.

Mertens, B., and E. F. Lambin. 1997. Spatial modelling of deforestation in southern Cameroon. Applied Geography 17:143-162.

Mertens, B., and E. F. Lambin. 2000. Land-coverchange trajectories in southern Cameroon. Annals of the Association of American Geographers 90:467-494.

Messerschmidt, D. A. 1987. Conservation and society in Nepal: traditional forest management and 
innovative development. Pages 373-397 in P. D. Little and M. M. Horowitz, with A. E. Nyerges, editors. Land at risk in the Third World: local level perspectives Westview, Boulder, Colorado, USA.

Moran, E. F., and E. Brondizio. 1998. Land-use change after deforestation in Amazonia. Pages 94120 in D. Liverman, E. F. Moran, R. R. Rindfuss, and P. C. Stern, editors. People and pixels: linking remote sensing and social science National Academy Press, Washington, D.nbsp;C., USA.

Müller-Böker, U. 1999. The Chitwan Tharus in southern Nepal: an ethnoecological approach. Translated by P. Pierce. Franz Steiner Verlag, Stuttgart, Germany.

Nagendra, H. 2001. Using remote sensing to assess biodiversity. International Journal of Remote Sensing 22:2377-2400.

Nagendra, H. 2002. Tenure and forest conditions: community forestry in the Nepal Terai. Environmental Conservation 29:530-539.

Nagendra, H., D. Munroe, and J. Southworth. 2004. Introduction to the special issue. From pattern to process: landscape fragmentation and the analysis of land use/land cover change. Agriculture, Ecosystems and Environment 101 (2-3):111-115.

Negi, S. S. 1998. Forests and forestry in Nepal. Ashish Publishing House, New Delhi, India.

Nepal, S. K., and K. E. Weber. 1994. A buffer zone for biodiversity conservation: viability of the concept of Nepal's Royal Chitwan National Park. Environmental Conservation 21:333-341.

Neupane, H. P. 2000. A grassroots organizer with a commitment to gender-balanced participation: an interview with Hari Prasad Neupane, Chairperson, Federation of Community Forestry Users in Nepal. Mountain Research and Development 20:316-319.

Ostrom, E. 1990. Governing the commons: the evolution of institutions for collective action. Cambridge University Press, New York, New York, USA.

Ostrom, E. 1998. The international forestry resources and institutions program: a methodology for relating human incentives and actions on forest cover and biodiversity. Pages 1-28 in F. Dallmeier and J. A. Comisker, editors. Forest biodiversity in North, Central and South America, and the Caribbean: research and monitoring. Man and the Biosphere Series, vol. 1. UNESCO, Paris, France, and Parthenon, New York, New York, USA.

Ostrom, E. 2000. Reformulating the commons. Swiss Political Science Review 6:29-52.

Palit, S. 1996. Comparative analysis of policy and institutional dimensions of community forestry in India and Nepal. Mountain Natural Resources Discussion Paper Series No. MNR 96/4. International Center for Integrated Mountain Development, Kathmandu, Nepal.

Petit, C., T. Scudder, and E. Lambin. 2001. Quantifying processes of land-cover change by remote sensing: resettlement and rapid land-cover changes in south-eastern Zambia. International Journal of Remote Sensing 22:3435-3456.

Poffenberger, M., and B. McGean, B., editors. 1996. Village voices, forest choices: joint forest management in India. Oxford University Press, Delhi, India.

Poteete, A. R., and E. Ostrom. 2004. Heterogeneity, group size and collective action: the role of institutions in forest management. Development and Change 35:435-461.

Poudel, K. 2000. Community forestry: government vs. community. News from Nepal as it happens 19 (47): 9-15 June 2000.

Poudel, K. 2001. Community forestry: under threat. News from Nepal as it happens 20(34): 09-15 March 2001.

Prasad, R., and S. Kant. 2003. Institutions, forest management and sustainable development: experiences from India. Environment, Development and Sustainability 5:353-367.

Ribot, J. C. 2002. Democratic decentralization of natural resources: institutionalizing popular participation. World Resources Institute, Washington, D. C., USA.

Ribot, J. C. 2004a. Decentralization of natural resource management: encountering and countering resistance. World Resources Institute, Washington, D. C., USA. 
Ribot, J. C. 2004b. Waiting for democracy: the politics of choice in natural resource management. World Resources Institute, Washington, D. C., USA.

Rindfuss, R. R., and P. C. Stern. 1998. Linking remote sensing and social science: the need and the challenges. Pages 1-27 in D. Liverman, E. F. Moran, R. R. Rindfuss, and P. C. Stern, editors. People and pixels: linking remote sensing and social science. National Academy Press, Washington, D. C., USA.

Schweik, C., and G. M. Green. 1999. The use of spectral mixture analysis to study human incentives, actions and environmental outcomes. Social Science Computer Review 17:40-63.

Schweik, C., H. Nagendra, and D. R. Sinha. 2003. Using satellites to search for forest management innovations in Nepal. Ambio 32:312-319.

Shreshtha, B. 1998. Changing forest policies and institutional innovations: user group approach in community forestry of Nepal. In Proceedings of the International Workshop on Community-Based Natural Resource Management (CBNRM), 10-14 May 1998, Washington, D. C., USA. World Bank Institute, Washington, D. C., USA. (Online.) URL: http://info.worldbank.org/etools/docs/library/97605/ conatrem/conatrem/html/Nepal-Paper.htm.

Stainton, J. D. A. 1972. Forests of Nepal. John Murray Publishers, London, UK.

Sundar, N. 2000. Unpacking the "joint" in joint forest management. Development and Change 31:255-279.

Suryanata, K., J. Fox, and S. Brennan. 2003. Issues of decentralization and federation in forest governance. Pages 1-8 in K. Suryanata, J. Fox, and S. Brennan, editors. Issues of decentralization and federation in forest governance. Proceedings of the Tenth Workshop on Community-based Management of Forestlands, 30 June-25 July 2003, East-West Center, Honolulu, Hawaii, and Regional Community Forestry Training Centre, Bangkok, Thailand.

Thapa, G. B., and K. W. Weber. 1995. Natural resource degradation in a small watershed in Nepal: complex causes and remedial measures. Natural Resources Forum 19:285-296.
Varughese, G. 1999. Villagers, bureaucrats, and forests in Nepal: designing governance for a complex resource. Dissertation, Indiana University, Bloomington, Indiana, USA.

Varughese, G. 2000. Population and forest dynamics in the hills of Nepal: institutional remedies by rural communities. Pages 193-226 in C. Gibson, M. McKean, and E. Ostrom, editors. People and forests: communities, institutions, and governance. MIT Press, Cambridge, Massachussetts, USA.

Varughese, G., and E. Ostrom. 2001. The contested role of heterogeneity in collective action: some evidence from community forestry in Nepal. World Development 29:747-765.

Wollenberg, E., B. Campbell, S. Shackleton, D. Edmunds, and P. Shanley. 2004. Collaborative management of forests. Pages 17-18 in R. S. Meinzen-Dick and M. D. Gregorio, editors. Collective action and property rights for sustainable development-2020 Focus 11. International Food Policy Research Institute, Washington, D. C., USA and CGIAR System-wide Program on Collective Action and Property Rights. 